\section{Dominik Tomasz Tomczyk}

Chrześcijańska Akademia Teologiczna

dt@dominiktomczyk.com

ORCID: 0000-0003-0023-9153

DOI: http://dx.doi.org/10.12775/BPTh.2021.004
Biblica

et

Patristica

Thoruniensia

14 (2021) 1: 97-110

ISSN (print) 1689-5150

ISSN (online) 2450-7059

\title{
Postrzeganie Pawła przez Piotra na podstawie zaimka „nasz" w 2 P 3,15
}

\section{Peter's perception of Paul based on the pronoun "our" in 2 Peter 3:15}

Streszczenie. Przedmiotem analiz w tym artykule jest fraza z 2 P 3,15: „Umiłowany nasz brat, Paweł”. Autor bada znaczenie użytego przez Piotra zaimka osobowego hēmōn („nasz”), który mówi o postrzeganiu Pawła przez Piotra. Paweł jest nie tylko „umiłowanym bratem” w wierze, ale przede wszystkim jest „bratem urzędu” w znaczeniu „bratem urzędu apostolskiego”, jaki sprawuje kolegium Dwunastu apostołów. Analiza czasowników w liczbie pojedynczej i mnogiej, jakie znajdują się w 1-2 P, pokazały, że Piotr nie posługuje się zaimkiem hēmōn jako pluralis majestaticus, ale jako rzeczywistą liczbą mnogą, ponieważ wypowiada się w imieniu Dwunastu i ich reprezentuje.

Abstract. The subject of an analysis in this article is the phrase from 2 Peter 3:15: "our beloved brother Paul". The author examines the meaning of the Greek personal pronoun hēmōn ("our") used by Peter, which illustrates how Peter perceived of Paul. Paul is not only called a "beloved brother" in faith but, above all, he is a "brother of office" in the sense of "brother of the apostolic office" held by the college of the Twelve Apostles. An analysis of singular and plural verbs found in 1 and 2 Peter shows that Peter does not use the pronoun hēmōn as pluralis majestaticus but as the real plural, because he speaks on behalf of the Twelve and represents them.

Słowa kluczowe: Drugi List św. Piotra; apostołowie; Dwunastu; św. Piotr; św. Paweł; brat; umiłowany.

Keywords: Second Epistle of St. Peter; the Apostles; the Twelve; St. Peter; St. Paul; brother; beloved. 
Badania Drugiego Listu Piotra ${ }^{1}$ dotyczą głównie zagadnień teologicznych: autorytetu Pisma Świętego i jego właściwej interpretacji, zagadnień chrystologiczno-soteriologicznych, nauczania etycznego czy ukierunkowania chrześcijańskiego życia ku eschatologii ${ }^{2}$. Bardzo trudno znaleźć w literaturze biblistycznej dedykowane analizy tekstu 2 P 3,15 badające postrzeganie Pawła przez Piotra w kontekście sprawowanego nowotestamentowego urzędu apostolskiego $^{3}$. A przecież ten aspekt jest kluczowy dla właściwej interpretacji służby i relacji obu apostołów.

Celem artykułu jest odpowiedź na pytanie, jak postrzega Pawła Piotr, jeden z Dwunastu apostołów Chrystusa, w kontekście zaimka osobowego „nasz” (hēmōn) w analizowanym tekście. Czy Piotr używa w tym przypadku formy pluralis wobec własnej osoby? Czy przez hēmōn rozumie on „nas” jako przynależących do grona Dwunastu czy też wszystkich wierzących w Pana? A może zaimek hēmōn wskazuje na Pawła jako pośrednika pomiędzy autorem listu a jego adresatami, wśród których to Paweł założył wspólnotę Kościoła?

Interesuje nas pełna analiza frazy z 2 P 3,15: „umiłowany nasz brat, Paweł” (ho agapētos hēmōn adelfos Paulos). W tym celu wykorzystana zostanie analiza gramatyczna i semantyczna wyrażeń używanych przez Piotra w ramach metody historyczno-krytycznej.

\section{Paweł jako „umiłowany" (agapētos)}

Piotr w dwóch swoich listach tylko raz wzmiankuje o Pawle. W jego Drugim Liście czytamy:

a cierpliwość Pana naszego uważajcie za zbawienną, jak to również umiłowany nasz brat, Paweł [ho agapētos hēmōn adelfos Paulos], według danej mu mądrości napisał do was, jak też we wszystkich [innych] listach, w których mówi o tym (2 P 3,15-16).

\footnotetext{
1 W kwestii autorstwa listu zob. F. Mickiewicz, List św. Judy, s. 161-169.

2 Por. ibidem, s. 184-203; idem, Główne tematy teologiczne, s. 23-42.

3 Por. M.G. Ruf, Die heiligen Propheten, s. 172-174; J. Frey, Exkurs: Zur Bedeutung der Paulusnotizin 2Petr 3,15b-16, s. 361-365; T. Nicklas, „Der geliebte Bruder“, s. 133-150; A. Vögtle, Petrus und Paulus, s. 223-239.
} 
Przymiotnik agapētos, którego używa Piotr, występuje w Nowy Testamencie 61 razy, zarówno w liczbie pojedynczej (27), jak i liczbie mnogiej (34), a niemal połowę znajdujemy w tekstach Pawła Apostoła (27 razy $)^{4}$. Synoptycy znają chrystologiczną formułę „syn umiłowany” (hyios agapētos), która odnosi się do Jezusa (por. Mt 3,17; 12,18; 17,5; Mk 1,11; 9,7; Łk 3,22;). „Umiłowany” to również syn właściciela winnicy w Jezusowej przypowieści o przewrotnych rolnikach (por. Mk 12,6; Łk 20,13).

„Umiłowany” (agapētos) i „umiłowani” (agapètoi) spotykamy jako tradycyjne pozdrowienie we wczesnych listach do chrześcijańskich wspólnot. Jest to pozarodzinny epitet określający wzajemną miłość, przywiązanie i solidarność. Kościół jest wspólnotą „umiłowanych w Panu” (agapētoi en kyriō). Agapētos wskazuje na obiektywną relację piszącego do adresatów listów, która oparta została na starożytnej analogii relacji ojciec - syn ${ }^{5}$. Przykładem może być Jan Ewangelista, który kierując swój Trzeci List do Gajusa nazywa go czterokrotnie „umiłowanym” (por. 3 J 1.2. 5. 11).

Bez wątpienia apagētos należy rozpatrywać w ramach Pawłowej „teologii miłości” ${ }^{6}$, jako preferowaną formę zwracania się chrześcijan do siebie nawzajem. Skoro chrześcijanie są agapētoi Boga, nie dziwi fakt tej samej analogii we wzajemnych relacjach ${ }^{7}$. Sam Paweł używa określenia agapētos wobec Epeneta (Rz 16,5), Ampliata (Rz 16,8), Stachysa (Rz 16,9), Tychika (Ef 6,21), Epafrasa (Kol 1,7), Onezyma (Kol 4,9; Flm 16), Łukasza (Kol 4,14), Filemona (Flm 1) czy Tymoteusza (1 Kor 4,17; 2 Tm 1,2).

Piotr posługuje się tym przymiotkiem 8 razy: 6 razy w liczbie mnogiej (agapētoi; 1 P 2,11; 4,12; 2 P 3,1. 8. 14. 17) i tylko 2 razy w liczbie pojedynczej (agapētos; 2 P 1,17; 3,15). Z jego wypowiedzi wynika, że Paweł jest przez niego uważany za „naszego umiłowanego brata”. Użyte tutaj greckie agapētos oznacza kogoś umiłowanego, godnego miłości, szanowanego, drogiego, cenionego, mile widzianego ${ }^{8}$. Jest to przymiotnik odsłowny o wyraźnym znaczeniu biernym ${ }^{9}$. Całe wyrażenie świadczy z pewnością o serdecznych stosunkach pomiędzy

4 Zob. R. Morgenthaler, Statistik, s. 67.

5 Por. O. Wischmeyer, Das Adjektiv АГАПНТО , s. 477-478.

6 Ibidem, s. 479: „å $\gamma \alpha \pi \dot{n}-$ Theologie”.

7 Ibidem, s. 477.

8 Por. W. Bauer, Griechisch-deutsches Wörterbuch, kol. 11-12 (odtąd: Bauer); J. Strong, Grecko-polski słownik, s. 5 \{G27\} (odtąd: Strong); Słownik grecko-polski, s. 7 (odtąd: Abramowiczówna, t. 1).

9 Zob A. Piwowar, Składnia języka greckiego, $\$ 136$. 
apostołami. Ze strony Piotra jest ono wyrażeniem szacunku i uznania roli, jaką odgrywał Paweł w pierwotnym Kościele oraz podkreśleniem jego oddania w służbie Chrystusa. Określenie to potwierdza pozytywny obraz Pawła, jaki przedstawia Piotr. Nie ma tutaj jakiegokolwiek ironicznego, pretensjonalnego czy innego negatywnego wydźwięku jego wypowiedzi ${ }^{10}$.

Wyrażenie „umiłowany brat” (ho agapētos adelfos) „określa Pawła nie tylko jako przyjaciela, czy współbrata w wierze, ale jako tego, z którym Piotr czuje się najbardziej związany w oficjalnej relacji”"11. W obliczu fałszywych nauczycieli, którzy chcieliby zdyskredytować położony przez Pawła fundament wiary, Piotr wskazuje na pełne harmonii osobiste relacje między nim a Apostołem Narodów ${ }^{12}$. Tym samym potwierdza on fakt, że Paweł reprezentuje „poprawną teologię apostolską" 13 .

\section{Paweł jako „brat” (adelfos)}

Przez termin ho adelfos pierwotnie oznaczano cielesne rodzeństwo, ale również brata, zarówno z tych samych obojga rodziców, jak i tylko z jednego wspólnego rodzica (np. Mt 1,2. 11; 4,18. 21; 10,2; Mk 1,6; 6,17; J 1,41; Dz 7,13 i inne). „Brat” to także ktoś posiadający tego samego przodka narodowego, należący do tego samego rodu, towarzysz bądź kuzyn (szczególnie w odniesieniu do krewnych Jezusa), a także współpracownik. W sensie przenośnym określał on duchowe braterstwo, chrześcijanina jako brata społeczności wierzących ${ }^{14}$. Możemy przypuszczać, że Piotr, intensyfikując użycie tego rzeczownika przez dodanie dopełnienia „nasz” (hēmōn), mógł mieć na myśli coś więcej niż tylko

10 Zob. H. Paulsen, Zur Literatur und Geschichte, s. 173; M.G. Ruf, Die heiligen Propheten, s. 191-193; F. Mickiewicz, Autorytet apostołów, s. 17. Przeciwnie G. Klein, Die Zwölf Apostel, s. 103: „Die Figur des Heidenapostels ist problematisch geworden und muß durch kirchlich sanktionierte Interpretation für die Orthodoxie erst noch domestiziert werden”.

11 J.E. Huther, Critical and Exegetical Handbook, s. 432.

12 Por. G.L. Green, Jude and 2 Peter, s. 278. logie".

13 A. Lindemann, Paulus im ältesten Christentum, s. 93: „richtige apostolische Theo-

$14 \mathrm{~W}$ takim kontekście występuje rzeczownik ho adelfos ok. 30 razy w Dz, zaś ponad 130 razy u Pawła. Por. Bauer, kol. 30-32; Strong, s. 14 \{G80\}; Abramowiczówna, t. 1, s. 25. 
łączność braterską we wspólnie wyznawanej wierze. K.H. Schelkle uważa, że Piotr powołuje się tutaj na „swego brata Pawła” w sensie „brata urzędu”15.

Taki właśnie sposób używania wyrażenia ho adelfos spotykamy u samego Pawła. Raz nazywa Tymoteusza „bratem naszym [ton adelfon hēmōn]” i sługą w głoszeniu Ewangelii Chrystusowej (1 Tes 3,2), zaś dwa razy używa wyrażenia ho agapētos adelfos wobec Tychika (zob. Ef 6,21; Kol 4,7). Prawdopodobnie całe wyrażenie - jako utarty już zwrot - mogło zostać zaczerpnięte przez Piotra z listów samego Pawła, skoro były one już mu znane, jeżeli nie wszystkie to chociaż pewna ich część ${ }^{16}$. Stwierdzenie Piotra, że „są w nich trudne do zrozumienia pewne sprawy, które ludzie niedouczeni i mało utwierdzeni opacznie tłumaczą, tak samo jak i inne Pisma, na własną swoją zgubę" (2 P 3,16) świadczy nie tyle o powierzchownej ich znajomości przez Kefasa, lecz o solidnym ich poznaniu.

Kim zatem jest Paweł w oczach Piotra? Posługując się jego słowami można powiedzieć, że „Paweł jest umiłowanym bratem Piotra”17. W takim też ujęciu zaimek hēmōn rozumiany byłby jako pluralis majestaticus. Piotr nie chcąc powiedzieć zbyt wiele o jego więzach uczuciowych łączących go z Pawłem, używa w tym celu liczby mnogiej. Wyraźne stwierdzenie ze strony Piotra, że Paweł jest dla niego hēmōn pokazuje, że napięcia pomiędzy nimi, o jakich wspominał Paweł w Ga 2,11-16, należą już do przeszłości a on sam wskazuje tu na pełną harmonii relację $\mathrm{z}$ apostołem pogan ${ }^{18}$.

Czy zatem Piotrowe hēmōn jest rzeczywiście pluralis majestaticus? Paweł w oczach Piotra jest z jednej strony „jego bratem”, z drugiej zaś strony jest on także „bratem urzędu”. Należy przyjąć właśnie takie rozumienie zwrotu ho agapētos adelfos, ale trudno jest uznać zaimek hēmōn za singularis Piotra w sensie „mój umiłowany brat”. Wydaje się, że winniśmy go rozumieć dosłownie, a więc jako pluralis. Wskazuje na to bliższa analiza literacka obu Piotrowych listów, ze szczególnym uwzględnieniem drugiego z nich.

15 Por. K.H. Schelkle, Die Petrusbriefe, s. 235: „Bruder bedeutet hier schwerlich nur den Glaubensgenossen (wie 1 Petr 2,17; 2 Petr 1,10), sondern den Amtsbruder (wie 1 Thess 3,2; Eph 6,21; Kol 4,7)".

16 F. Mickiewicz uważa, że „już w drugiej połowie I wieku chrześcijanie znali jakiś bliżej nieokreślony zbiór listów Pawła”. Idem, List św. Judy, s. 339.

17 K.H. Schelkle, Die Petrusbriefe, s. 235: „Paulus ist der geliebte Bruder des Petrus”.

18 D.F. Watson, T. Callan, First and Second Peter, s. 216. 


\section{Liczba pojedyncza i mnoga czasowników w Listach Piotra}

W 1 P formę singularis czasownika spotykamy 3 razy $(2,11 ; 5,1$. 12), a w 2 P 4 razy $(1,12.13 .15 ; 3,1)$. Podobnie jest $\mathrm{z}$ liczbą mnogą: gdy w $1 \mathrm{P}$ nie występuje ona w ogóle, to w 2 P spotykamy ją 4 razy $(1,16.18$. 19; 3,13). Tabela 1 zestawia omawiane formy.

Tabela 1. Formy 1 os. 1. poj i 1. mn. w 1 i 2 P

\begin{tabular}{|c|c|c|c|}
\hline \multicolumn{2}{|c|}{1 List Piotra } & \multicolumn{2}{|c|}{2 List Piotra } \\
\hline 1 os. l. poj & 1 os. $1 . \mathrm{mn}$ & 1 os. 1. poj & 1 os. $1 . \mathrm{mn}$ \\
\hline $\begin{array}{l}2,11 \text { proszę [parakalō], } \\
\text { abyście jak przybysze } \\
\text { i goście }\end{array}$ & brak & $\begin{array}{l}1,12 \text { będę zawsze wam } \\
\text { przypominał [mellēsō] }\end{array}$ & $\begin{array}{l}\text { 1,16 postępowaliśmy } \\
\text { wtedy, gdy daliśmy } \\
\text { wam poznać } \\
\text { [egnōrisamen] moc } \\
\text { i chwałę }\end{array}$ \\
\hline $\begin{array}{l}\text { 5,1 proszę [parakalō], } \\
\text { ja również starszy }\end{array}$ & & $\begin{array}{l}1,13 \text { uważam [hēgoumai] zaś } \\
\text { za słuszne pobudzać (...) } \\
\text { dopóki jestem [eimi] w tym } \\
\text { namiocie }\end{array}$ & $\begin{array}{l}\text { 1,18 i słyszeliśmy } \\
\text { [ēkousamen], jak ten } \\
\text { głos doszedł z nieba }\end{array}$ \\
\hline \multirow[t]{2}{*}{$\begin{array}{l}\text { 5,12 wam napisałem } \\
\text { [egrapsa] przy } \\
\text { pomocy Sylwana }\end{array}$} & & $\begin{array}{l}\text { 1,15 starać się będę } \\
\text { [spoudasō], abyście zawsze } \\
\text { mieli sposobność }\end{array}$ & $\begin{array}{l}1,19 \text { mamy [echomen] } \\
\text { jednak mocniejszą, } \\
\text { prorocką mowę }\end{array}$ \\
\hline & & $\begin{array}{l}\text { 3,1 piszę [grafō] do was } \\
\text { ten już drugi list; w nich } \\
\text { pobudzam [diegeirō] wasz } \\
\text { zdrowy rozsądek }\end{array}$ & $\begin{array}{l}\text { 3,13 oczekujemy } \\
\text { [prosdokōmen] } \\
\text { jednak, według } \\
\text { obietnicy }\end{array}$ \\
\hline
\end{tabular}

W 1 P 5,1 Piotr występuje jako „współstarszy” (sympresbyteros), który kieruje swoją prośbę do „starszych” (presbyterous) tamtejszych gmin: „Starszych więc, którzy są wśród was, proszę [parakalō], ja również starszy [sympresbyteros], a przy tym świadek [martys] Chrystusowych cierpień oraz uczestnik tej chwały, która ma się objawić". Rzeczownik sympresbyteros oznacza współstarszego zarówno w sensie współkierującego społecznością, jak i kogoś w podobnym wieku ${ }^{19}$. Tytuł ten stawia Piotra jako współbrata

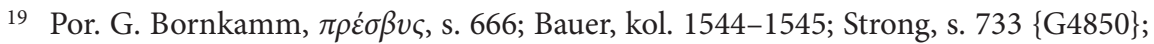
S. Hałas, Pierwszy List św. Piotra, s. 325. 
obok i wśród innych. Podkreśla tym samym - z wyraźną skromnością - wykonywanie wspólnej (jednej i tej samej) posługi w dziele zbawienia człowieka. „Ich zadanie jest jego zadaniem, ich trud jest jego trudem, lecz jego obietnica jest także ich obietnicą" ${ }^{20}$. Piotr - jako sympresbyteros wśród innych presbyterous - podkreśla swoją współodpowiedzialność za chrześcijańskie wspólnoty Jezusa na terenach wiejskich w głębi ówczesnej Azji Mniejszej, do których kieruje swój list ${ }^{21}$. Fakt, że Piotr był jednym $\mathrm{z}$ wielu naocznych świadków Jezusa ziemskiego i Chrystusa zmartwychwstałego, stawia go ipso facto wyżej od „starszych”, jak również daje mu prawo do udzielania napomnień i pouczeń. Piotr występuje tu jako duchowo-moralny autorytet; jako ostateczna i decydująca o wszystkim instancja, od której nie ma już jakiegokolwiek odwołania; jako rzeczywisty apostoł Chrystusa i jeden z Dwunastu (zob. 2 P 1,16-17).

Pozostałe teksty liczby pojedynczej zarówno w $1 \mathrm{P}(2,11 ; 5,12)$ jak i w $2 \mathrm{P}$ $(1,12.13 .15 ; 3,1)$ nie posiadają charakteru „urzędowego". Są to formy znane i obiegowe zarazem.

Liczbę mnogą czasownika w Drugim Liście Piotra spotykamy w czterech miejscach: 1,16. 18. 19; 3,13. Dotyczą one raz ogółu chrześcijan (2 P 1,19; 3,13), raz Dwunastu (2 P 1,16. 18).

Tekst z 2 P 1,19: „Mamy jednak mocniejszą, prorocką mowę”, wydaje się być elementem łączącym apostołów i wiernych w jedną całość wspólnoty kościoła $^{22}$. Jest ona drogocennym i pełnym największych obietnic depozytem wiary, jaki został powierzony w pierwszej kolejności Dwunastu przez ich Mistrza z Nazaretu, którzy następnie głosili Dobrą Nowinę wraz z innymi w Jego imieniu „aż po krańce ziemi” (Dz 1,8). Tym samym zwiastowana przez nich Ewangelia królestwa Bożego stała się udziałem adresatów Piotrowego listu.

Podmiotem dla orzeczenia „mamy” (echomen) nie są już tylko apostołowie, którzy byli świadkami przemienienia Jezusa (w. 18). Echomen „ogarnia wszystkich członków Kościoła, których skarbem jest słowo prorockie”23, na

\footnotetext{
20 K.H. Schelkle, Die Petrusbriefe, s. 127-128.

21 Zob. S. Hałas, Pierwszy List św. Piotra, s. 34-41; tutaj: s. 39.

22 Por. F. Gryglewicz, Listy Katolickie, s. 282.

23 F. Mickiewicz, List Św. Judy, s. 254.
} 
co wskazuje ogólny sposób zwracania się przez Piotra do wierzących w kolejnych wierszach ${ }^{24}$.

Podobnie jest z tekstem 2 P 3,13: „oczekujemy [prosdokōmen] jednak, według obietnicy nowego nieba i nowej ziemi, w których zamieszka sprawiedliwość”, który możemy traktować jako tekst dotyczący „nas” w sensie „nas wszystkich chrześcijan".

Natomiast teksty: 2 P 1,16 („Nie za wymyślonymi bowiem mitami postępowaliśmy wtedy, gdy daliśmy wam poznać [egnōrisamen] moc i przyjście Pana naszego, Jezusa Chrystusa, ale jako naoczni świadkowie [epoptai] Jego wielkości”) i 1,18 („I słyszeliśmy [ēkousamen], jak ten głos doszedł z nieba, kiedy z Nim razem byliśmy [ontes; dosł. będąc] na górze świętej") wyraźnie wskazują na apostołów należących do Dwunastu. W drugim przypadku chodzi o Piotra, Jakuba i Jana, świadków przemienienia Jezusa na „świętej górze" (por. Mt 17,1-12 i par.). Naocznymi świadkami Chrystusa (epoptai), o których Piotr mówi w w. 16, mogą być tylko Jego uczniowie, spośród których wybrał i ustanowił kolegium Dwunastu (por. Mk 3,13-19; Mt 12,15-21; Łk 6,12-16). Bycie epoptai z 2 P 1,16, które nawiązuje z pewnością do autoptai z Łk $1,2^{25}$, podkreśla nie tylko naocznych świadków, ale „do obrazu naocznego świadka dodaje ideę pilnego przyglądania się czemus'”26. I dlatego apostołowie zaświadczają o wielkości Chrystusa w stosunku do głoszonych fałszywych mitów przez pseudonauczycieli.

Ponadto Piotr w 2 P 1,16 używa czasownika gnōridzō, który w grece klasycznej oznacza m.in. podawanie do wiadomości, a także uzyskanie gruntownego poznania czegoś (w tym objawienia Bożej prawdy) lub też zaznajomienie się z kimś, poznanie kogoś27. Oto Jezus oznajmił swoim uczniom

24 Jeżeli przyjmiemy, że otwierający w. 19 spójnik „i” (kai) jest kai epexegeticum (lub explicativum), to wówczas następujące po nim echomen kontynuuje i potwierdza wcześniej wyrażoną myśl o potwierdzeniu słów prorockich. Wówczas „mamy” (echomen) odnosiłoby się do „słyszeliśmy” (ēkousamen) z w. 18. Wydaje się to jednak mało prawdopodobne, ponieważ kai epexegeticum należy do rzadkich konstrukcji w jęz. greckim. Por. A. Piwowar, Składnia języka greckiego, \$523. Przeciwnie H. Strachan, The Second Epistle General of Peter, s. 131: „Thus we have still further confirmation of the words of the prophets”.

25 Zarówno epoptai jak i autoptai są hapax legomenon w Nowym Testamencie i w swoim zakresie pola semantycznego oznaczają niemal to samo.

26 F. Mickiewicz, Autorytet apostołów, s. 15. Por. idem, List Św. Judy, s. 248; G.L. Green, Jude and 2 Peter, s. 220-221; Bauer, kol. 604; Strong, s. 304-305 \{G2030\}.

27 Bauer, kol. 324; Strong, s. 163 \{G1107\}; Abramowiczówna, t. 1, s. 474. 
wszystko, co usłyszał od swego Ojca (por. J 15,15), teraz zaś Piotr - jak i Dwunastu - dzieli się tym, co poznał, co usłyszał osobiście, czego doświadczył podczas towarzyszenia Jezusowi w Jego ziemskiej działalności.

Ich posługiwanie, szczególnie od momentu zmartwychwstania, jest posługiwaniem w imię Chrystusa. Stąd też ich kerygmat, który jest orędziem niosącym zbawienie en Christō (por. Dz 4,12), może mieć i rzeczywiście ma znamię prorockie, o czym wspomina Piotr. Podkreśla on ponadto łączność pomiędzy prorokami Starego Testamentu a apostołami Jezusa, pisząc: „abyście przypomnieli sobie słowa, które były dawno już przepowiedziane przez świętych proroków, oraz przykazanie Pana i Zbawiciela, podane przez waszych apostołów [tōn apostolōn]" (2 P 3,2). To właśnie apostołowie Chrystusa są pomostem pomiędzy Bożym słowem Starego Testamentu, głoszonym przez proroków, a Bożym słowem Nowego Testamentu, głoszonym przez Jezusa, a po Jego śmierci i zmartwychwstaniu przez nich samych. Prorocy Starego Testamentu oraz apostołowie Nowego Testamentu są wysłannikami Boga na wzór ich Mistrza z Nazaretu, którego Ojciec posłał, aby pojednać świat ze sobą. To apostołom Jezus wraz z Ojcem powierzył „słowo jednania” (zob. 2 Kor 5,19). To „słowo jednania” jest słowem w służbie Ewangelii (zob. 1 Tm 1,12), jest „słowem prorockim” (profētikon logon).

\section{Zaimek osobowy „my” (hēmeis) w Listach Piotra}

Zaimek osobowy jest jednym z najczęściej występujących zaimków w Nowym Testamencie (prawie 11 tys razy) ${ }^{28}$. Przy jego pomocy podkreślamy relację jednego podmiotu w stosunku do drugiego. Dlatego też warto zwrócić uwagę na sposób używania przez Piotra zaimka osobowego hēmeis = „my”. Tabele 2 i 3 prezentują wszystkie miejsca występowania pierwszej („my”) i drugiej („wy”) osoby liczby mnogiej, jakie znajdujemy w obu Piotrowych listach, w tym również odmienione przez przypadki.

28 Por. A. Piwowar, Składnia języka greckiego, \$151. 
Tabela 2. Deklinacja 1 os. l. mn. w 1 i 2 P

\begin{tabular}{|c|c|c|c|}
\hline Przypadek & $\mathbf{1}$ osoba liczby mn. & $\mathbf{1} \mathbf{P}$ & $\mathbf{2} \mathbf{P}$ \\
\hline mianownik & hēmeis & & $1,18$. \\
\hline dopełniacz & hēmōn & 1,$3 ; 2,24 ; 4,17$. & $\begin{array}{c}1,1.2 .11 .14 .16 ; 3,15 \\
(2 \times) .18 .\end{array}$ \\
\hline celownik & hēmin & & $1,1.3 .4$. \\
\hline biernik & hēmas & 1,$3 ;$ & 1,$3 ; 3,9$. \\
\hline
\end{tabular}

Tabela 3. Deklinacja 2 os. 1. mn. w 1 i 2 P

\begin{tabular}{|c|c|c|c|}
\hline Przypadek & 2 osoba liczby mn. & $1 \mathrm{P}$ & $2 P$ \\
\hline mianownik & hymeis & 2,$9 ; 4,1$ & 3,17 . \\
\hline dopełniacz & hymōn & $\begin{array}{c}\text { 1,7.9.13.14.17.18.21. } \\
\text { 22; 2,12(2x).21.25; } \\
\text { 3,2. 7. 15.16; 4,4.15; } \\
\text { 5,7(2x). 8. } 9\end{array}$ & 1,5.10. 19; 3,1. 2 \\
\hline celownik & hymin & $\begin{array}{c}1,2.12(2 \mathrm{x}) .13 ; 2,7.21 \\
3,15 ; 4,12(3 \mathrm{x}) ; 5,1.2 \\
12.14\end{array}$ & $\begin{array}{c}\text { 1,2. 8. 11. 16; 2,1.13; } \\
\text { 3,1.15. }\end{array}$ \\
\hline biernik & hymas & $\begin{array}{c}\text { 1,4. 10.12.15.20.25; } \\
\text { 2,9; 3,13.15.18.21; } \\
4,14 ; 5,6 \cdot 10.13\end{array}$ & $\begin{array}{c}1,12.13 .15 ; 2,3 ; 3,8 . \\
9.11\end{array}$ \\
\hline
\end{tabular}

Analiza zaimka osobowego hēmeis wskazuje, że dotyczy on trzech głównych grup osób, do których się odnosi. Grupa 1 tekstów dotyczy Jezusa Chrystusa jako „Pana naszego” (1 P 1,3; 2,24. 25; 2 P 1,1. 2. 8. 11. 14; 3,15); grupa 2 dotyczy wszystkich wierzących chrześcijan (1 P 1,2. 3. 4. 7. 9. 10. 12. 13. 14.15. 17. 18. 20. 21. 22. 25; 2,7. 9. 12. 21; 3,2. 7. 13. 15. 16. 18. 21; 4,1. 4. 12. 14. 15. 17; 5,1. 2. 6. 7. 8. 9. 10. 12. 13. 14; 2 P 1,1.2. 3. 5. 8. 10.11. 12. 13. 15. 16; 2,1. 3. 13; 3,1. 8. 9. 11. 15. 17), zaś grupa 3 dotyczy Dwunastu apostołów (2 P 1,4. 16. 18. $19 ; 3,15)$.

$\mathrm{Na}$ podstawie przeanalizowanych wcześniej tekstów możemy stwierdzić, że liczba mnoga tak czasownika, jak i zaimka dotyczy bezpośrednio apostołów należących do grona Dwunastu, ale także ogółu wierzących w Chrystusa. W analizowanym tekście 2 P 3,15 Piotr używa aż dwukrotnie formy dopełniacza. Za pierwszym razem mówi o cierpliwości „Pana naszego” (hēmōn), za 
drugim zaś o „ukochanym naszym [hēmōn] bracie, Pawle”. „Nasz Pan” - to Jezus Chrystus, który po swoim chwalebnym zmartwychwstaniu stał się Panem wszystkich (por. Flp 2,10-11) ${ }^{29}$. W drugim przypadku wydaje się, iż chodzi tu o „nasz” w sensie Dwunastu, których reprezentuje sam Piotr (por. Mt 16,18-19). Paweł jest więc „bratem urzędu” - jak słusznie zauważył K.H. Schelkle - ale jest on nade wszystko „bratem urzędu” apostolskiego, takiego samego, jaki reprezentuje Piotr, Jakub czy Jan lub też „pozostali wielcy apostołowie”30. Tym samym apostolskie posługiwanie Pawła zostaje uznane przez Piotra za równe posługiwaniu Dwunastu apostołów. Dla Piotra Paweł jako ho agapētos hēmōn adelfos ma tak samo równe i niepodważalne prawa do bycia apostołem Chrystusa jak pozostali z grona Dwunastu ${ }^{31}$. Paweł nie stoi już tylko na czele swoich współpracowników, z którymi głosił Dobrą Nowinę nieobrzezanym, ale teraz sam jest bezpośrednim współpracownikiem Piotra - co podkreśla Piotrowe hēmeis ${ }^{32}$. Obaj są postrzegani jako „braterski duet”, jako „dwuosobowa drużyna" w służbie tej samej Ewangelii ${ }^{33}$.

Założenie to znajduje swe potwierdzenie w 2 P 3,1-2, gdzie Piotr tylko raz używa wyrażenia ,apostoł” (apostolos). Czytamy tam:

Umiłowani, piszę do was już ten drugi list; w nich pobudzam wasz zdrowy rozsądek i pamięć, abyście przypomnieli sobie słowa, które były dawno już przepowiedziane przez świętych proroków, oraz przykazanie Pana i Zbawiciela, podane przez waszych apostołów [tōn apostolōn hymōn].

Trudno jest jednoznacznie stwierdzić, czy ci, którzy głosili Słowo Boże pośród tych wspólnot kościelnych, do których zwraca się obecnie Piotr, byli rzeczywistymi apostołami, czy też tylko ich pełnomocnikami. Przyjmując, że to Paweł wraz ze swoim towarzyszem wypraw misyjnych - Barnabą dał początki chrześcijaństwu w północnych prowincjach Azji Mniejszej, tekst ten może

29 Termin „Pan” (kyrios) w 2 P nie jest jednoznaczny, ponieważ odnosi się zarówno do Boga jak i do Chrystusa. F. Mickiewicz zakłada, że „Pan” „jest wyraźnie tytułem Jezusa Chrystusa. To pozwala zrozumieć, że Piotr mówi o Jezusie Chrystusie w taki sam sposób jak o Bogu". Idem, Główne tematy, s. 29.

30 K.H. Schelkle, Die Petrusbriefe, s. 235.

31 Zob. H. Paulsen, Der zweite Petrusbrief, s. 173: „Für ihn handelt es sich um den

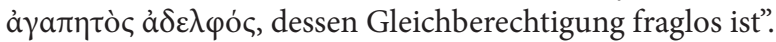

32 Por. M.G. Ruf, Die heiligen Propheten, s. 192.

33 Por. F. Mussner, Petrus und Paulus, s. 67. 
dotyczyć właśnie ich, pomimo braku ich imion. Byłoby to zrozumiałe, gdyż odbiorcy Piotrowego listu bez trudu wiedzieliby o kogo mu chodzi. W przeciwnym wypadku chodziłoby tu o nieznanych Piotrowi, a dobrze znanych tamtejszym kościołom, ewangelistów, których on określa wyrażeniem „wasi apostołowie” (tōn apostolōn hymōn). Można by wówczas mówić o tzw. „wysłannikach kościołów" (apostoloi ekklēsiōn), o których wspomina Paweł w 2 Kor 8,23 i Flp 2,25. Jednak użyty w tym przypadku rodzajnik określony (tōn) sugeruje, iż Piotr ma na myśli konkretne, znane mu skądinąd osoby, być może właśnie Pawła i Barnabę.

Połączenie tekstu 2 P 3,2 z 2 P 3,15 pozwala na następujący wniosek: Paweł jest apostołem, a jako taki jest "naszym bratem” mającym pełny udział w „naszym” posługiwaniu, tzn. posługiwaniu Dwunastu. Choć nie jest członkiem kolegium, ponieważ nie został do niego wybrany przez Jezusa ziemskiego spośród jego uczniów (por. Mk 3,13-18 i par.), to jednak jest takim samym apostołem Chrystusa, jak każdy z nich. Zatem w oczach Piotra - Paweł znajduje się w bardzo ścisłej łączności z gronem Dwunastu. Łukasz w Dz 15,25 daje o tym następujące świadectwo: „postanowiliśmy [apostołowie i starsi bracia - D.T.] jednomyślnie wybrać mężów i wysłać razem z naszymi drogimi [tois agapētois hēmōn]: Barnabą i Pawłem”. Paweł stał się „ich bratem” w urzędzie apostolskim na podstawie tego samego mandatu, jaki Dwunastu otrzymało od Chrystusa po Jego chwalebnym zmartwychwstaniu (por. Mt 28,16-20; Mk 16,15-18), a jaki Paweł otrzymał u bram Damaszku (por. Dz 9,1-16; 22,3-21; 26,12-19).

\section{Podsumowanie}

Badanie frazy: „umiłowany nasz brat, Paweł” (ho agapētos hēmōn adelfos Paulos) w 2 P 3,15 w kontekście postrzegania Pawła przez Piotra pokazało, że obu apostołów Jezusa Chrystusa uznawało powołanie i obdarowanie drugiego (zob. Ga 2,7-10). Wydarzenie opisane w Ga 2,11-21 już dawno odeszło w zapomnienie i nie doprowadziło do jakiegokolwiek podziału pomiędzy świadkami Zmartwychwstałego.

Piotrowe "nasz brat" należy rozumieć nie tyle jako brata w wyznawanej wierze, ile w sensie „brata Dwunastu”, „brata nas apostołów”, „brata urzędu” w służbie głoszenia Ewangelii (por. 2 Kor 1,1; 8,18. 22. 23; Ef 6,21; Kol 1, 1; 4,7; 1 Tes 3,2; Flm 1; 1 P 5,12). Tym samym Piotrowe hēmōn nie oznacza jego 
pluralis majestaticus, ale liczbę mnogą dotyczącą kolegium Dwunastu apostołów Jezusa Chrystusa.

\section{Bibliografia}

Bauer W., Griechisch-deutsches Wörterbuch zum Neuen Testament zu den Schriften des Neuen Testaments und der übrigen urchstilichen Literatur, wyd. 5, Berlin-New York 1971.

Bornkamm G., $\pi \rho \varepsilon \dot{\sigma} \beta v \varsigma$. Theologisches Wörterbuch zum Neuen Testament (hrsg. G. Friedrich), Bd. VI, Stuttgart 1959, s. 651-680.

Frey J., Exkurs: Zur Bedeutung der Paulusnotizin 2Petr 3,15b-16, w: idem, Der Brief des Judas und der zweite Brief des Petrus, Theologischer Handkommentar zum Neuen Testament 15/II, Leipzig 2015, s. 361-365.

Green G.L., Jude and 2 Peter, Baker Exegetical Commentary on the New Testament, Grand Rapids 2008.

Gryglewicz F., Listy Katolickie. Wstęp - Przekład z oryginału - Komentarz, Pismo Święte Nowego Testamentu XI, Poznań 1959.

Hałas S., Pierwszy List św. Piotra. Wstęp. Przekład z oryginału. Komentarz, Nowy Komentarz Biblijny Nowy Testament XVII, Częstochowa 2007.

Huther J.E., Critical and Exegetical Handbook to the General Epistles of James, Peter, John, and Jude, New York 1887.

Klein G., Die Zwölf Apostel. Ursprung und Gestalt einer Idee, Forschungen zur Religion und Literatur des Alten und Neuen Testaments 77, Göttingen 1961.

Lindemann A., Paulus im ältesten Christentum. Das Bild des Apostels und die Rezeption der paulinischen Theologie in der frühchristlichen Literatur bis Marcion, Beiträge zur historischen Theologie 58, Tübingen 1979.

Mickiewicz F., Autorytet apostołów w Kościele pierwotnym w świetle Drugiego Listu św. Piotra, Seminare 39 (2018) nr 2, s. 11-21.

Mickiewicz F., Główne tematy teologiczne Drugiego Listu św. Piotra, Collectanea Theologica 88 (2018) nr 1, s. 23-42.

Mickiewicz F., List św. Judy. Drugi List św. Piotra. Wstęp. Przekład z oryginału. Komentarz, Nowy Komentarz Biblijny. Nowy Testament XVIII, Częstochowa 2018.

Morgenthaler R., Statistik des neutestamentlichen Wortschatzes, Zürich 1958.

Mussner F., Petrus und Paulus - Pole der Einheit. Eine Hilfe für die Kirchen, Questiones Disputatae 76, Freiburg 1976.

Nicklas T., „Der geliebte Bruder“. Zur Paulusrezeption im zweiten Petrusbrief, w: Der zweite Petrusbrief und das Neue Testaments, W. Grünstäudl, U. Poplutz, T. Nicklas (red.), Wissenschaftliche Untersuchungen zum Neuen Testament 397, Tübingen 2017, s. 133-150.

Paulsen H., Der zweite Petrusbrief und der Judasbrief, Kritisch-exegetischer Kommentar über das Neue Testament XII/2, Göttingen 1992. 
Paulsen H., Zur Literatur und Geschichte des frühren Christentums. Gesammelte Aufsätze, Wissenschaftliche Untersuchungen zum Neuen Testament 99, U.E. Eisen (red.), Tubingen 1992.

Piwowar A., Składnia języka greckiego Nowego Testamentu, Materiały pomocnicze do wykładów z biblistyki 13, Lublin 2017.

Ruf M.G., Die heiligen Propheten, eure Apostel und ich. Metatextuelle Studien Zum Zweiten Petrusbrief, Wissenschaftliche Untersuchungen zum Neuen Testament II 300, Tübingen 2011.

Schelkle K.H., Die Petrusbriefe. Der Judasbrief, Herders Theologischer Kommentar zum Neuen Testament XIII/2, wyd. 2, Freiburg-Basel-Wien 1964.

Słownik grecko-polski, t. 1: A- $\Delta$, Z. Abramowiczówna (red.), Warszawa 1958.

Strachan H., The Second Epistle General of Peter, The Expositor's Greek Testament 5, Grand Rapids 1983.

Strong J., Grecko-polski słownik Stronga z lokalizacją słów greckich i kodami Popowskiego, przekł. A. Czwojdrak, Warszawa 2015.

Vögtle A., Petrus und Paulus nach dem Zweiten Petrusbrief, w: Konitinuität und Einheit. Festschrift für Franz Mussner, zum 65. Geburtstag, P.G. Müller, W. Stenger (red.), Freiburg 1981, s. 223-239.

Watson D.F., C. Terrance, First and Second Peter, Paideia Commentaries on the New Testament, Grand Rapids 2012.

Wischmeyer Oda, Das Adjektiv АГАПНТО $\Sigma$ in den paulinischen Briefen. Eine traditionsgeschichtliche Miszelle, New Testament Studies 32 (1986) nr 3, s. 476-480. 